\title{
Reducing emissions from land use in Indonesia: motivation, policy instruments and expected funding streams
}

\author{
Meine van Noordwijk • Fahmuddin Agus • Sonya Dewi • \\ Herry Purnomo
}

Received: 14 August 2013 / Accepted: 15 August 2013 / Published online: 24 September 2013

(C) The Author(s) 2013. This article is published with open access at Springerlink.com

\begin{abstract}
Land-based emissions of carbon dioxide derive from the interface of forest and agriculture. Emission estimates require harmonization across forest and non-forest data sources. Furthermore, emission reduction requires understanding of the linked causes and policy levers between agriculture and forestry. The institutional forestry traditions dominated the emergence of the discourse on Reducing Emissions from Deforestation and forest Degradation (REDD+) while more holistic perspectives on land-based emissions, including agriculture, found a home in international recognition for Nationally Appropriate Mitigation Actions (NAMAs). We tested the hypothesis that, at least for Indonesia, the NAMA framework provides opportunities to resolve issues that REDD+ alone cannot address. We reviewed progress on five major challenges identified in 2007 by the Indonesian Forest Climate Alliance: 1) scope and 'forest' definition; 2) ownership and tenurial rights; 3) multiplicity and interconnectedness of drivers; 4) peatland issues across forest and non-forest land categories; and 5) fairness and efficiency of benefitdistribution mechanisms across conservation, degradation and restoration phases of tree-cover transition. Results indicate that the two policy instruments developed in parallel with competition rather than synergy. Three of the REDD+ challenges can be resolved by treating REDD+ as a subset of the NAMA and national emission reduction plans for Indonesia. We conclude that two issues, rights and benefit distribution, remain a major challenge, and require progress on a motivational pyramid of policy and polycentric governance. National interest in retaining global palm oil exports gained priority over expectations of REDD forest rents. Genuine concerns over climate change motivate a small but influential part of the ongoing debate.
\end{abstract}

Keywords Land-based emissions $\cdot$ Multiple scales $\cdot$ NAMA $\cdot$ Policy analysis $\cdot$ REDD +

\footnotetext{
M. van Noordwijk $(\bowtie) \cdot S$. Dewi

World Agroforestry Centre (ICRAF), Southeast Asia Regional Office, Situ Gede, Bogor 16115, Indonesia e-mail: m.vannoordwijk@cgiar.org
}

F. Agus

Indonesian Soil Research Institute, Bogor, Indonesia

H. Purnomo

Center for International Forestry Research (CIFOR) and Faculty of Forestry, Bogor Agricultural University, Bogor, Indonesia 


\section{Introduction}

Carbon emissions from tropical deforestation and degradation, including the draining and burning of peat swamps in Southeast Asia average $1.4( \pm 0.5) \mathrm{Pg} \mathrm{yr}^{-1}$ (Houghton 2012), while global net anthropogenic emissions now exceed $10 \mathrm{Pg} \mathrm{yr}^{-1}$ (Peters et al. 2012). Emissions related to land use in Southeast Asia thus are some $14 \%$ of the global total and warrant attention. Indonesia is responsible for a large share of the Southeast Asian total and is a key country for achieving emission reduction from land use. There may also be more specific arguments to address the intersection of air pollutants and greenhouse gasses that relate to biomass burning and land-cover change (Unger 2012).

The motivation to reduce emissions might ultimately derive from the United Nations Framework Convention on Climate Change (UN FCCC), which nearly all nations have ratified, but specific (proximate) policy instruments and funding streams have been created (but are not yet fully functional) to support achievement of the UN FCCC's ultimate objective. The sticks of law enforcement, carrots of funding streams, and sermons reinforcing motivation need to align in effective policy triads (Bemelmans-Videc et al. 1998). Two policy instruments started as parallel elements of the Bali Roadmap agreed at the UN FCCC Conference of Parties in 2007: efforts to Reduce Emissions from Deforestation and (forest) Degradation (REDD+) and the articulation of Nationally Appropriate Mitigation Actions (NAMAs). While the scope of REDD+ has been gradually broadened (Olander et al. 2012), the two have been largely treated as independent or even competing approaches. REDD+ and NAMA have had separate international negotiation platforms, separate communities of practitioners, policymakers and researchers trying to push the envelope, with little cross-referencing (Luttrell et al. 2012; Murdiyarso et al. 2012; Mulyani and Jepson 2013).

According to the Scholar.Google database accessed on 2 November 2012, the probability that references including the term REDD or REDD+ also included the term NAMA was $12.9 \%$ and $2.9 \%$, respectively, while the probabilities that the much smaller body of literature that mentions NAMA also included the term REDD or REDD+ was $53.2 \%$ and $50.9 \%$, respectively. While we can only guess at the reasons for this differential and selective reference to the two sibling policy instruments, the two concepts represent different pathways to link the common goal of global emission reduction mandated by the UN FCCC from its start at the United Nations Conference on Environment and Development in 1992 through to operational mechanisms that are institutionalized, mainstreamed and internalized. The emphasis on nationally appropriate in NAMA suggest a different positioning in the sovereignty issue that is critical in developing country's negotiaton positions in the UN FCCC (Melkas 2002), while the REDD+ discourse has from its start been linked to expectations of substantive new financial flows towards developing countries (Angelsen and Rudel 2013). As discussed here, a remarkable synergy between the two has emerged in Indonesia over the past 5 years, but the underlying motivation and tactics have been challenged.

We will review the interface of the NAMA and REDD+ discussions, with a focus on (inferred or expressed) motivation, policy instruments and expectations of funding streams. We focus on Indonesia, as it has been reported (IFCA 2007) to have the highest emissions from land use among all countries, hosts the largest area of tropical peat and the third-largest tropical rainforest in the world, with forest officially covering about $70 \%$ of the country's 183 million ha land area. As part of the country's development strategies, this forest has been subject to, and is still undergoing, rapid transition to non-forest uses and to intensive timber plantations to meet the country's target of $7 \%$ annual economic growth. The converted forests include those on peat. Emissions from peat forest fires and peat decomposition have been estimated to be more than $50 \%$ of the country's emissions, which totalled about $0.5 \mathrm{Pg} \mathrm{yr}^{-1}$ of carbon in 2005 (MoF 2010). 
Indonesia has also played a special role in both the REDD+ and NAMA debates as host of the UN FCCC conference of parties (COP) in 2007. It became an early implementer of REDD, even with its high rates of land-based emissions in global biodiversity hotspots, consistently growing economy and human population, and its major contribution to global agricultural and forestry exports. Indonesia also became known as a country where transparency of government, commitment to decentralization and openness of public debate made a quantum leap in the 1997 political change, yet corruption and lack of transparency remain major concerns (Dermawan et al. 2011; Krott et al. 2013). Indonesia became a global trail-blazer in its early articulation of NAMA through a commitment to unilaterally reduce its emissions by $26 \%$ below the expected business-as-usual (BAU) scenario for 2020, and $41 \%$ if supported by international funding, across all sectors within the national boundaries. Forty-one per cent below the $2020 \mathrm{BAU}$ is approximately equal to the reported emission levels for 2005. Indonesia also became a hotspot of debate about the role export-oriented agriculture and forestry activities (palm oil, pulp and paper) played in its emission profile and how self-regulation plus import policies influenced emissions (Butler et al. 2009; Tata et al. 2013).

Our main hypothesis is that, at least for Indonesia, the framework for articulating NAMA provides opportunities to resolve issues that REDD+ cannot address in isolation in identifying funding streams for policy instruments that match the motivation to mitigate global climate change.

To test the hypothesis, we focused on a list of five challenges to REDD that were indentified in discussions of the 2007 Indonesian Forest Climate Alliance (IFCA) that pioneered much of subsequent international and national debates on REDD and introduced a phasing of REDD+ efforts that was adopted globally (IFCA 2007). Based on the authors direct involvement in the 5 years of public and individual learning following the IFCA start, we will here review the progress of REDD+, NAMA and other mechanisms to achieve international recognition for, and investment in, efforts to reduce land-based emissions in Indonesia across the forestry-agroforestry-plantations - agriculture spectrum of land uses on peat and mineral soils.

\section{Motivational pyramid as conceptual framework}

As the hypothesis refers to motivation, we needed a conceptual framework for the multiple types of motivation encountered or inferred from the actions of government entities and other actors to engage in discussions about, and actions toward, emission reduction.

Current understanding in behavioural economics (Kahneman 2011) suggests that the human brain in its different parts makes decisions on behaviour that are subsequently rationalized and communicated as if they were rational. Recently, a distinction was made between five scales of economics (van Noordwijk et al. 2012): the pico scale of brain synapses involved in primary responses to threats and opportunities; the micro scale of individual or household livelihood strategies; the meso scale of social systems and environmental economics, where the undesirable effects of microeconomic decisions on external stakeholders are internalized; the macro scale of a national economy and its multiple goals; and the giga economic scale of ecological economics and the efforts to reconcile human actions and existing planetary boundaries. Motivations expressed in rationalizations of behaviour can incorporate any of the four scales beyond pico-economics therefore stated reasons may be suspect in the light of observed behaviour.

Maslow (1943) formulated a theory of inferred human motivation in line with observations and experimental evidence at the time, in which five human goals are layered (and 
conventionally depicted as a pyramid): physiological needs (health, food, water, sleep); safety (shelter, removal from danger); belonging (love, affection, being part of groups); esteem (self-esteem and esteem from others); and self-actualisation (achieving individual potential). Subsequent work has developed further classification systems, focussed on a dichotomy between the first two as biological needs and the others as social needs. However, the basic concept of a motivational pyramid has maintained its appeal. Costanza et al. (2007) reviewed literature on the quality of life as an approach integrating opportunities, human needs, and subjective well-being, extending beyond the Maslow pyramid. They applied it at both individual and national scales. To our knowledge, the concept of a motivational pyramid has not yet been linked to policy decisions on issues such as mitigation of climate change yet it might help us understand the low sense of priority about climate change unless it directly addresses issues of national security, urban food supply systems and/or economic growth. It might also help in recognize conflicting messages that reduce rather than enhance the motivation to work in synergy.

Derived from discussions with practitioners and policy analysts, Fig. 1 suggests that there is a motivational pyramid of issues that drive government policies within which mainstreaming of any environmental issue, such as climate change, has to take place. The specific labels for the layers and the number of layers themselves are tentative and open to further refinement and revision. The bottom three (territorial integrity, food security and economic growth) have been widely recognized as fundamentals that no policy maker can afford to neglect (Tadjbakhsh and Chenoy 2007). We tentatively separate the motivation for participation in global trade at bulk good level from that to achieve recognized, branded commodity status, as studied in value-chain analysis (Fitter and Kaplinksy 2001).

The motivational pyramid of governance interacts with a demotivational tetragon of rentseeking elites whose political survival depends mostly on the lower levels of the pyramid. Figure 1 also indicates the three phases identified by IFCA (MOF 2010): I. Awareness; II. Readiness; III. Implementation at scale. Possible implementation modes differ in their entry point to the motivational pyramid. REDD + and NAMA are primary paths to reduce Indonesia's emissions but discussions about the emissions embodied in trade (EET; Minang et al. 2010) also have entered public discourse, with the international acceptability of export products such as palm oil at stake if associated with deforestation and emissions. REDD + is being promoted as replacing 'forest rent' with 'REDD+ rent' as a public income source but net benefits will only occur if REDD+ rents exceed the foregone opportunity costs of other options and/or if the forested landscape conditions supported by REDD+ has other direct or indirect benefits locally. NAMA, in the sense of self-articulated programs, allows for a much stronger expression of core identity, more self-esteem and the 'feel-good' aspect of being a responsible global citizen. In between these two, there are mechanisms related to EET where branding as a responsible producer country maintains export opportunities and global market share.

\section{Study design and methods}

To test the hypothesis we started from a list of key challenges to successful emission reduction in Indonesia through REDD or similar mechanisms that were identified ahead of the 2007 COP of the UNFCCC (van Noordwijk et al. 2008a).

1. The need for clarity of scope, given the existence of multiple definitions of forest and the discussions in Indonesia about the experience of afforestation/reforestation as part of the 


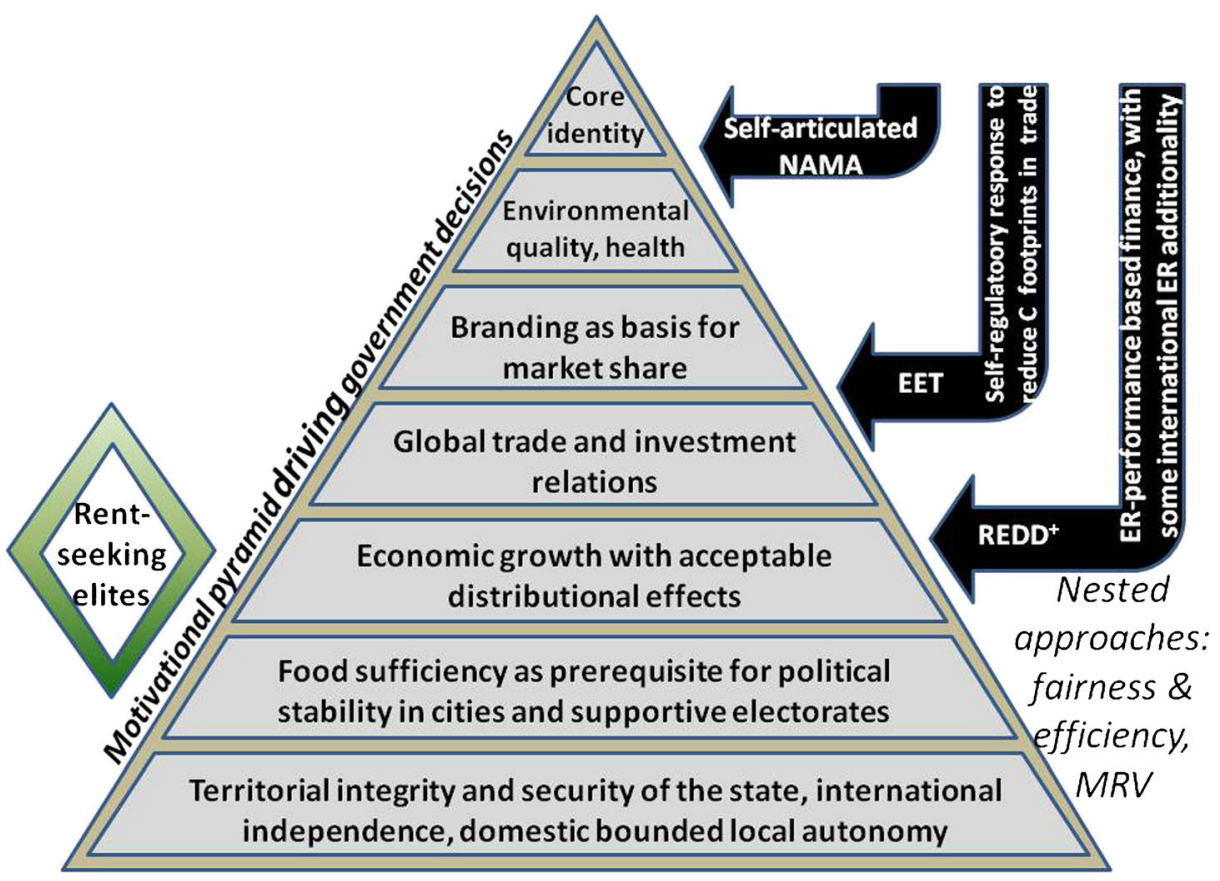

Fig. 1 A conceptual model of the way knowledge/awareness, a motivational pyramid of governance decisions and various approaches to achieve global emission reduction interact; EET Emissions Embodied in (international) Trade; $E R$ emission reduction; $M R V$ monitoring, reporting and verification; NAMA nationally appropriate mitigation actions; REDD $+=$ reducing emissions from deforestation, (forest) degradation

Clean Development Mechanism, where the institutional concept of forest (forest lands are all those designated to be forest, managed by the Ministry of Forestry) dominated rather than that based on tree cover and carbon stock (van Noordwijk et al. 2008b).

2. The need to recognize the complexity of multiple stakeholders' rights to forests, analyze tenurial conflicts and deal with the unresolved legality of the very partial gazettement of designated forest areas.

3. The need for cross-sectoral integration because drivers of deforestation and forest degradation are partially outside of the forestry sector and root-cause solutions have to involve investment that are also from outside of the forestry sector.

4. The need to include peatland that is inside or outside the 'forest' categorization as a target for action, recognizing the landscape-hydrological relations in peat domes that defy partial solutions.

5. The challenges of meeting both fairness and efficiency concerns in actions along the forest transition curve that include large variations in immediacy of expected emissions; the legality of, and links to, government planning of the activities that lead to emissions; prospects for recovery of terrestrial carbon stocks; and variations in poverty rates and the Human Development Index (Murdiyarso et al. 2008).

We subjected these five challenges to a review of progress in seeking implementation modalities for REDD+ and NAMA in Indonesia, which all authors are involved with, as well as reflections on that process in the scientific literature and publicly accessible documents. 
Other contributions in this special issue give more detailed accounts of efforts at local levels. These include the recognition of complexity in interactions involving migrants (Galudra et al. 2013), exploration of local development scenarios in peat swamp areas in Aceh (Tata et al. 2013) and Jambi (Lusiana et al. 2013; Mulia et al. 2013), multi-level stakeholder discussions and application of agent-based and system modelling techniques (Purnomo et al. 2012, 2013) and the combination of role-play games, agent-based models and household surveys (Villamor et al. 2013). In the absence of fully articulated research methods that can represent this conceptualization of motivation, we use it in qualitative discussion mode to describe and interpret the progress and setbacks in discourse at national and sub-national scales.

\section{Results: progress on the list of IFCA issues}

\subsection{Clarity of scope and the institutional concept of forest}

The forest and deforestation data reported by Indonesia have so far been restricted to the forest zone (kawasan hutan) - a land-use planning and institutional concept (the zone is the mandate of the Ministry of Forestry) - ignoring tree cover on other land even if some of this is natural forest. Interpretation of satellite imagery is not limited to such institutional classifications but mandates to represent, and take responsibility for, data (and its errors) are. A simple two-by-two table (or Venn diagram) showing forests and non-forests both with and without trees helped explain the issue and became part of the standard repertoire (van Noordwijk et al. 2009). Calculations for the Berau district in East Kalimantan showed that conversion of the tree-based carbon stock outside the formal forest zone could maintain current emission levels for more than 5 years (Ekadinata et al. 2010) and that claims for emission reduction inside the forest zone might thus have a leakage potential of more than $100 \%$ within a 5-year timeframe. This case supported the wider conclusion that credible carbon accounting of any REDD+ scheme would have to be based on the whole landscape: restricting activities and incentives to part of the domain for which accountability has to be absorbed probably increases rather than decreases transaction costs. In a recent study, Romijn et al. (2013) confirmed the importance of the operational, rather than the institutional, forest definition for REDD+ in Kalimantan.

Quantification of tree-cover change across all of Indonesia established a strong dependence of the deforestation rate and its temporal change on the definition of forest used (Fig. 2). The annual deforestation rate (the probability that a unit of land changes from forest to non-forest status in a year's time) peaked at $4.85 \%$ for an untouched natural forest based on calculations for the period 2000-2005 and became negative $0.5 \%$, indicating an increase in forests, for the weakest, most inclusive forest definition for 2005-2010. The effect of time on deforestation rates, however, remained smaller than the effect of forest definition.

The NAMA commitment by Indonesia ( $26 \%$ emission reduction below 2020 BAU) expressed in the national action plan for greenhouse gas emission reduction (RAN-GRK) will rely mostly on reduction of land-based emissions (Thamrin 2011; Santosa et al. 2013). This relates to carbon accounting for all land uses and is effectively independent of the definition of forest used, as long as realistic carbon accounting procedures are followed.

\subsection{Tenure conflict}

The designation of forest lands in Indonesia and the associated mandate of the Ministry of Forestry has been interpreted as implying state ownership but the law separates the two 

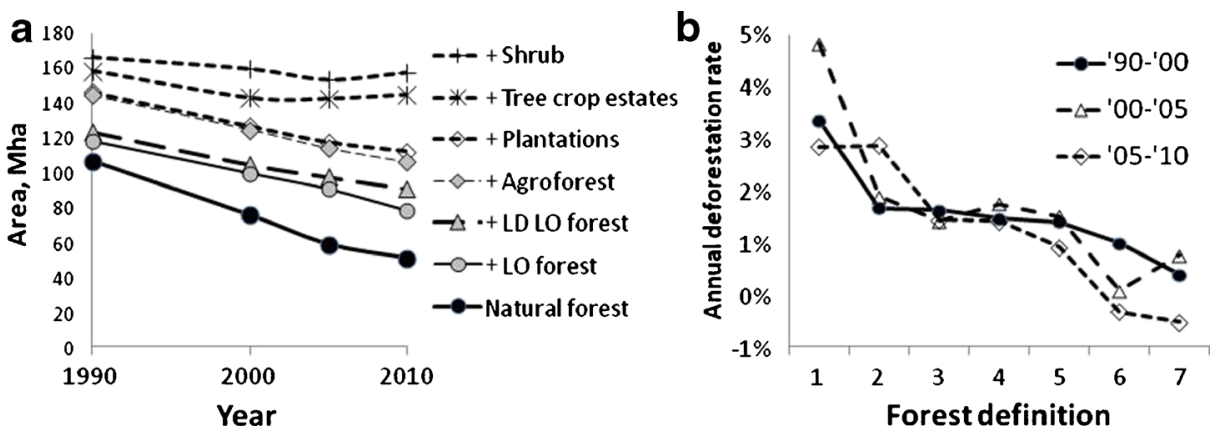

Fig. 2 a Change in tree cover in Indonesia based on interpretation of satellite imagery and $\mathbf{b}$ dependence of annual deforestation rate on the land-cover-based forest definition used for three time periods (1990-2000, 2000-2005 and 2005-2010); LO logged over; LD low density. Operational 'forest' definitions include diverse forest types: 1 . Natural forest; 2 . As for 1 plus logged-over forest; 3 . As for 2 plus heavily logged, low-density forest; 4 . As for 3 plus agroforest; 5 . As for 4 plus forestry plantations; 6 . As for 5 plus tree crop plantations; 7. As for 6 plus shrubs (still within the UNFCCC definition). Data sources: ALREDDI 2011; Ekadinata et al. 2011

concepts. The IFCA report (IFCA 2007; van Noordwijk et al. 2008a) cited data that only $10 \%$ of the area classified as forest zone had been demarcated through the legal requirements of a forest delineation process. This left more than half of the country uncertain as to the nature of associated rights and a questionable forest zone legality (Contreras-Hermosilla and Fay 2005; World Bank 2007).

Yet, the lack of legality of the claim of the Ministry of Forestry over more than half of the country remained unaddressed and in the last 5 years there has been no substantial progress on gazettement. The expectations of REDD funding fueled discord over fairness between local stakeholders and the government and also between district and provincial governments and the Ministry of Forestry. At the start of the Central Kalimantan REDD pilot project, analyses identified this as a major issue (Galudra et al. 2011) but the project went ahead without clarifying the various claims. The recent closure of the project ${ }^{1}$ was a result of mismatching local and external expectations.

In 2012, the Indonesian constitutional court ruled, in a case initiated by local governments from the province of Central Kalimantan, that the ambiguity the 1999 Forestry Law (Law no. 41/1999) had created in allowing either 'designation' or 'gazettement' to be the basis for inclusion of land areas in the permanent forest estate in its article 1(3) should be resolved by relying on gazettement only (Wells et al. 2012). Only 14.2 million ha (10.9\%) of the 130.7 million ha of the forest zone ( $68.4 \%$ of Indonesia's landmass) has to date been gazetted in compliance with the law, creating a legal vacuum around all government rules and permits for the rest of the area.

A further ruling by the Indonesian constitutional court on 16 May 2013 accepted a judicial review of key clauses of Law no. 41/1999, removing ambiguity about whether indigenous people's forest management was recognized or not (it now is). The consequences of this ruling for specific REDD+ projects in preparation or pilot modes have yet to be clarified.

The IFCA discussions were part of a trend in which the issue of tenurial conflict became widely acknowledged as one of the root causes of forest degradation in Indonesia (Brockhaus et al. 2011). Legal instruments for negotiated solutions under the Village

\footnotetext{
${ }^{1}$ See http://www.iafcp.or.id/content/page/44/KFCP; http://news.mongabay.com/2013/0703-kfcp-to-endausaid.html
} 
Forest (Hutan Desa) category of community forest management (Hutan Kemasyarakat) received a boost (Akiefnawati et al. 2010). The procedures for such designation, however, are complex and require consent by local government as well as forestry officials from local to national levels. Commitments were made as part of the REDD+ national strategy to increase the reach of such negotiated instruments from the current $0.1 \%$ to about $5 \%$ of the country. If achieved, it will represent a compromise solution. In the meantime, the constitutional court ruling requires new negotiations between local governments and the Ministry of Forestry to rationalize land-use designations and allow a more comprehensive perspective on land-based emissions.

\subsection{Multiple, interacting drivers of deforestation}

Data on the proportion of different land-cover fractions (Fig. 2) imply that drivers of forest conversion in Indonesia vary between the islands and have shifted over time between logging (decreasing area of intact natural forest, increasing area of logged over forest or shrub), fire (linked to changes in vegetation due to logging), conversion to tree crop plantations and plantation forestry, intensification of crop-fallow rotations (van Noordwijk et al. 2008c; Mertz et al. 2012) and expansion of open-field agriculture. The potential profitability of tree crops, combined with increased road access and government-sponsored transmigration programs that brought in a rural labour force, have driven the expansion of a semi-industrial form of agriculture. This has relied on a type of forest conversion that depends on the land/labour ratio, which is influenced by rural development and accessibility planning. These decisions outside the forestry sector dominate what happens with the forest and incentives for modifying decisions need to reach such decision makers rather than being focused on the forest managers who, at best, protect remaining forests from the symptoms rather than root causes of change.

The concept of tree-cover or forest transitions (Meyfroidt and Lambin 2011) has replaced more abstract notions of an environmental Kuznetz curve (Culas 2007) and points to greater geographic specificity of the dynamics that generate the land-use patterns and associated carbon emissions. The IFCA (2007) study used the forest transition curve at conceptual level and this has become common practice (Angelsen and Rudel 2013). Comparing the Asian pattern of deforestation and associated drivers with that in Latin America, it is remarkable that extensive cattle ranging has never emerged in Asia while it is still an important part of the forest conversion value chain and lack of advanced forest transition stages in the Amazon. The continental geography of supply and demand in higher latitude zones (USA versus Australia) may explain most of it but at the intensive end of the land-use spectrum the emergence of a dairy industry has complex interactions with forest conservation (Lusiana et al. 2012).

The rise of a forest industry based on plywood after the 1990s log export ban was followed by the rise of a particle board and pulp and paper industry that could valorize the smaller trees left after logging. Widely blamed on illegal logging, the overcapacity of the pulp and paper industry relative to the sustainable supply (World Bank 2007) secured a demand that still cannot be met by the forest plantation sector, partly because tenurial conflict slows down plantation expansion. REDD + goals can only be achieved if the incentives change for higher-level planning decisions, as well as on-the-ground implementation. Articulation of national and sub-national emission reduction plans for land-based emissions, including REDD+, has made it easier to deal with the full range of relevant drivers of forest change. 


\subsection{Peatland issues}

Emissions from Peatland are considered the main source of emissions in Indonesia (Hooijer et al. 2010; MoF 2010) such that avoidance of the use of peat forests, be they located in or outside the forest zone, will lead to globally relevant emission reduction. However, peatland is not evenly distributed over Indonesia and a limited number of districts in Riau, Jambi, Central Kalimantan and East Kalimantan provinces dominate current emissions from peatland while a number of others have the potential to join this list. Land swaps of existing concessions and development plans to mineral soils, if any such soils are available within the same district, is a delicate matter under the current regulatory setting. The problem will be far more complicated if it is applied across different districts. Therefore, a total halt of agricultural land expansion on peatland does not seem plausible. Water management by keeping the water table as high as possible to a level that does not negatively affect production will reduce emissions from peatland (Wösten et al. 2008; Agus et al. 2013) but integrating peatland use in broader land-use planning inside and outside of the forest zone is needed. An incentive approach linked to emission reduction per se, rather than emission reduction within the forestland categories, would help in the effectiveness and efficiency of national emission reduction planning.

\subsection{Benefit distribution mechanisms}

There are challenges of meeting both fairness and efficiency concerns in actions across the forest transition curve that include large variations in the immediacy of expected emissions; the legality of, and links to, government planning of the activities that lead to emissions; the prospects for recovery of terrestrial carbon stocks; and variations in poverty rates and the Human Development Index (Murdiyarso et al. 2008). The fairness versus efficiency trade off for Indonesia and the way it is perceived by local stakeholders is further discussed by Lusiana et al. (this issue).

\section{Global state of play of REDD+ and NAMA}

Seven years after the start of international negotiations on REDD+ (from 2005 with reducing emissions from deforestation (RED); Pistorius 2012), the structure and flows of REDD+ finance remain uncertain (Streck 2012). There still is no agreement on the magnitude and sources of funding, the role of the private sector and market-based mechanisms, or the modalities of disbursing international REDD+ funds. Pragmatic use of the various sources of finance is essential to avoid further delays and frustrations with REDD+ implementation (Edwards et al. 2012; Venter and Koh 2012). REDD+ monitoring, reporting and verification (MRV) systems remain a site of political conflict (Gupta et al. 2012). There is a risk that REDD+ may become a lose-lose instrument leading to irreversible commodification and tradability of forests, exacerbating North-South conflicts and marginalizing local communities (Gupta 2012). Corbera (2012) reviewed the emerging REDD+ policy framework as the world's largest experiment to date in payments for ecosystem services (PES) through commodification of ecosystems' carbon storage and sequestration functions. REDD+, thus, alternates between an ethically informed conservation discourse about the need for global emission reduction and a utilitarian concept that simplifies nature to a tradable commodity, undermining socio-ecological resilience and crowding-out conservation motivations. The largely unresolved issue of resource use rights and tenure security in the tropical forest 
margins (Chhatre et al. 2012; Larson 2011; Lyster 2011) further complicates PES-type REDD+ incentive mechanisms that involve a 'right to sell' carbon emission reduction credits. The challenges around tenure faced in Indonesia are common to other countries experimenting with REDD (Sunderlin et al. 2013; Resosudarmo et al. 2013). Van Noordwijk et al. (2012) discussed two complementary paradigms to commodification: compensation and co-investment. Both can be seen as part of the broad PES concept in the sense that they aim at internalization by local decision makers of externalities that are of value to external stakeholders. It may be feasible to combine multiple paradigms across scales (see below).

Technical aspects of how to achieve and quantify emission reduction have thus been overwhelmed by the challenges of creating a platform for fairness plus efficiency in a world that has divergent rather than convergent political agendas and where motivation to seriously deal with anthropogenic climate change is still weak (Clark et al. 2011). Co-investment suggests that emission issues are dealt with as an outcome of high carbon-stock development pathways (Minang et al. 2012), rather than as stand-alone targets, in an era of multi-actor and polycentric governance (Newell et al. 2012).

\section{Discussion}

In summary, the development of land-based climate mitigation in Indonesia over the last 5 years suggests that three out of the five REDD challenges (1, 3 and 4) identified by IFCA in 2007 could be resolved by embracing REDD+ as part of a more comprehensive landbased NAMA approach in Indonesia (Thamrin 2011). This made the issues of 'forest' definition and scope, the inclusion of peatland and the interactions at driver level more manageable through integration on a larger, landscape-scale planning and accounting system rather then restricting actions to the forest zone as such. Two other issues (rights and benefit distribution) might well be as complex in NAMA as they are in REDD+. Returning to our hypothesis that, at least for Indonesia, the framework for articulating NAMA provides opportunities to resolve issues that REDD+ cannot address in isolation, we found positive indications for three, and mixed results for two, issues.

The congruence and intersection of REDD+ and NAMA can be viewed from the perspective of REDD+ proponents - that of global emission reduction - and that of the Indonesian government: balancing economic growth, distributional fairness and environmental issues and image. However, even if the perspectives converge, the institutional processes toward readiness are more often in parallel rather than in a synergy-seeking mode, fuelled by expectations of directing funding streams. The two primary institutions are Satgas REDD+, led (until June 2013) by the presidential task force (Unit Kerja Presiden Bidang Pengawasan dan Pengendalian Pembangunan), and the land-based NAMA, namely the working group for the land-based sector led by the national planning agency Bappenas. They have separate communication channels. There is a real danger that synergy applies only within the conceptual sphere and not in planning and implementation. Leadership in bridging the two apparently parallel processes is urgently needed before the gaps grow larger once Indonesia enters the implementation phase. At the time of writing (mid 2013), the REDD+ pilot provinces are discussing setting reference emission levels without reference to the methods and the emission levels that were applied for the subnational land-based NAMA as part of the $0.58 \mathrm{Pg} \mathrm{C} \mathrm{yr}^{-1}$ emission targeted by Indonesia for 2020 .

As for addressing multiple and interacting drivers of land-use changes, it is yet to be seen that advances towards efficient interventions can indeed be reached because they require intersectoral coordination, despite the accommodating platform created for this purpose 
(Irawan et al. 2013). Currently within the land-based sector, forestry, land-use changes, peatland and agriculture are all included but often each component is treated as independent from the others, especially agriculture and the others. Yet, the rural economy is based on integration. Interdependencies among the components and integration with development needs are being established, mostly through land-use planning to reach both emission reduction and development goals that are mainstreamed as sustainable landscapes and green economy (Dewi et al. 2012).

Two issues, rights (2) and benefit sharing (5) are still as challenging as they appeared in 2007. Questions of emission reduction generally progress through an environmental issue cycle (Tomich et al. 2004) and move from the how, what, where? through by whom?, who'll have to pay? to how to align diverse stakes and stakeholders?. The challenges to move from a basic understanding to action are mostly linked to rights, costs and expected benefit sharing.

The motivational ladder of Fig. 1 suggests that issues of territorial integrity and food security dominate over emission reduction. In the Indonesian context, the partial political autonomy of Aceh and Papua allowed the governors of these provinces to be early movers on internationally supported $\mathrm{REDD}^{+}$, only to be corrected and brought back under the control of national authorities who set the bounds of regional autonomy. The motivational pyramid suggested three entry points for government policy to achieve internationally coordinated global emission reduction: A) the prospects of REDD+ money as a source of forest rent that can replace and, if possible, exceed the opportunity costs of foregone development efforts and their associated rents; B) the effect of Indonesia's international image and brand on its export opportunities, acknowledging new footprint standards pioneered for biofuel trade, but influencing commodities more widely; C) real concerns over global climate change, the urgency of achieving global emission reduction, the lack of additionality in offset mechanisms of financing, and the pride of being a responsible global citizen, articulating sovereignty. Motivations A, B and C are not automatically synergistic and prospects of substantial REDD+ rent (motivation $\mathrm{A}$ ) increased the initial attention of local and national policy makers but did not match intrinsic motivation $\mathrm{C}$. While the rent-seeking elites are well versed in tapping into legal and illegal forest rent, they are seeking entry points into REDD + rent. There is substantial literature on rent seeking in the forest sector in general but also specific application to the emerging carbon markets (Van Kooten et al. 2012).

The international debate has not been able to resolve the funding mechanism and the associated signs of additionality in achieving global emission reduction (Brown and Peskett 2011). While most REDD+ efforts so far have involved new funding, the concept of a carbon market with tradable emission rights is still seen by many as a necessary next step to achieve the finance levels needed. The offset concept, however, implies zero additionality for global emission reduction and leads to conflicting messages at the higher motivational levels. It will not address global climate change and it puts developing countries in the role of poorly paid cleaning service.

While NAMA has appeal at this highest motivational level of self articulation at national scale, it does not have the same value at local level, unless it is based on articulation of locally appropriate mitigation actions aligned with the NAMA. Nor does it by itself have direct economic benefits. It probably assists at the EET and REDD+ levels, however. Indonesia's name was at stake when it became associated with forest destruction and high emissions. In this context, the commitment made by Indonesia's president to reduce emissions with the country's own resources through NAMA and establish a good name in the process (incidentally, in Indonesian nama means 'name') helped in building a positive image 
and future market share. The voluntary commitment by the president was seen by many in the REDD+ discourse as unnecessary step that would deprive the country and especially its forest sector from a source of income. The commitment to take action by Indonesian authorities probably, however, helped to bring REDD + funds on board because it moved Indonesia closer to an optimal threat level. The willingness to engage from the outside in addressing environmental issues depends on a combination of threat and trust: while low threat reduces the relevance of engaging, low trust is a deterrent (van Noordwijk et al. 2011). The Letter of Intent between Norway and Indonesia and the commitment to invest USD 1 billion in Indonesia followed the NAMA commitment. Further steps in the process and the release of funds required Indonesia's action, such as the moratorium on logging and forest conversion permits. Yet, very little of the committed funds have so far been disbursed, largely due to the complexity of intersectoral cooperation. As complex as it is, a comprehensive approach might well be needed to avoid the recognized flaws of the Clean Development Mechanism. The fact that the Mechanism takes a project-by-project approach to establishment, verification and certification of additionality has been linked to opportunities for fraudulent outcomes (Drew and Drew 2010).

Van Noordwijk et al. (2012) discussed commodification, compensation and coinvestment as three paradigms within the PES concept and posed that a multi-scale approach can match paradigms to the way permanence, leakage and additionality can be handled when local scales interact with district/provincial and national scales (Fig. 3). At national scale, ownership and accountability allow for a commodification approach; at sub-national scale, compensation might be the key paradigm while, more locally, co-investment is still applicable even when rights issues remain to be resolved and the interconnection is so strong that leakage and additionality are insurmountable issues for partial project approaches that are not embedded in a broader accountability bubble. Broader land-use planning approaches that include conservation areas, account for landscape-wide emissions and employ land-use change scenarios are an essential part of sub-national approaches (Minang and van Noordwijk 2012; Dewi et al. 2013; Phelps et al. 2012 and Venter et al. 2012). Such a multi-paradigmatic, multi-scale approach combining commodification, compensation and co-investment across scales, however, is still a major communication challenge even if it

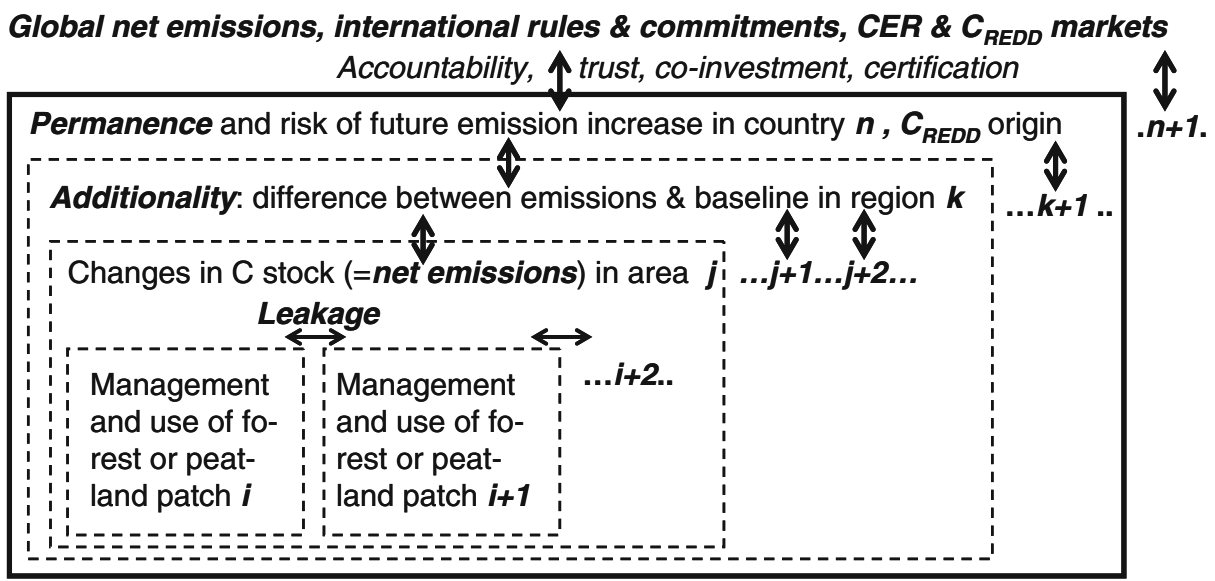

Fig. 3 Nesting of the scales at which the management and use of any forest or peatland patch interacts with global net greenhouse gas emissions, and the scales at which leakage, additionality, permanence and risk can be addressed. CER certified emission reduction 
allows for a more synergistic approach that matches motivational challenges at the various scales. Local involvement in measurement and monitoring (Danielsen et al. 2013) can be an important steps towards locally appropriate mitigation actions, but current practice is not achieving this potential.

The pathway chosen for Vietnam, adding a carbon perspective to existing water-based forest management incentives (Hoang et al. 2012) is probably not applicable in the more complex governance context of Indonesia.

\section{Conclusion}

Whereas REDD+ was originally shaped as a stand-alone mechanism focussed on the forests of developing countries, the interactions between forests and the rest of the landscape at the levels of drivers, patterns of change, actors, stakeholders and consequences proved to be so strong that a more holistic, overarching approach to land use was needed. Indonesia's pioneering use of the NAMA approach does now allow forests and other land-use categories to be handled through common planning and policy instruments. Complementary funding streams and synergy is in reach between levels of motivation that relate to core values, to genuine concerns with global climate change, and an active role in global commodity trade. New investment is needed in compensation of stakeholders for foregone opportunities that would have resulted in disproportionately high emissions. From five major challenges foreseen for REDD+ at its start in Indonesia, three can be resolved in the broader NAMA context, but the issues of rights to land, forests and trees, as well as the expected benefit distribution rules and mechanisms are as contested and sensitive now as they were 5 years ago. While NAMA is rooted in sovereignty concepts and REDD+ is focused on financial flows, new pathways to high carbon stock (low emission) economic development need to combine the best of the two.

Acknowledgments This research was supported by the European Community's Seventh Framework Programme [FP7/2007-2013] under grant agreement no. 226310 as part of the REDD-ALERT project and by the CGIAR Research Program on Forests, Trees and Agroforestry.

Open Access This article is distributed under the terms of the Creative Commons Attribution License which permits any use, distribution, and reproduction in any medium, provided the original author(s) and the source are credited.

\section{References}

Agus F, Gunarso P, Sahardjo B et al. (2013) Historical $\mathrm{CO}_{2}$ emissions from land use and land use change from the oil palm industry in Indonesia, Malaysia and Papua New Guinea. Roundtable on Sustainable Palm Oil, Kuala Lumpur (in press)

Akiefnawati R, Villamor G, Zulfikar F et al (2010) Stewardship agreement to reduce emissions from deforestation and degradation (REDD): case study from Lubuk Beringin's Hutan Desa, Jambi Province, Sumatra, Indonesia. Int For Rev 12:349-360

ALREDDI (2011) Accountability and Local Level Initiative to Reduce Emission from Deforestation and Degradation in Indonesia. World Agroforestry Centre (ICRAF), Southeast Asia Regional Program, Report 288-13, Bogor, Indonesia, p 114

Angelsen A, Rudel T (2013) Designing and implementing effective REDD+ policies: a forest transition approach. Rev Environ Econ Pol 7(1):91-113 
Bemelmans-Videc M, Rist R, Vedung E (eds) (1998) Carrots, sticks, and sermons: policy instruments and their evaluation. Transaction, New Brunswick

Brockhaus M, Obidzinski K, Dermawan A et al (2011) An overview of forest and land allocation policies in Indonesia: is the current framework sufficient to meet the needs of REDD+? For Pol Econ. doi:10.1016/ j.forpol.2011.09.004

Brown J, Peskett L (2011) Climate finance in Indonesia: lessons for the future of public finance for climate change mitigation. Working Paper no. 11. Overseas Development Institute, London

Butler R, Koh L, Jaboury Ghazoul J (2009) REDD in the red: palm oil could undermine carbon payment schemes. Cons Lett 2:67-73

Chhatre A, Lakhanpal S, Larson A et al (2012) Social safeguards and co-benefits in REDD+: a review of the adjacent possible. Curr Op Sust. doi:10.1016/j.cosust.2012.08.006

Clark W, Tomich T, van Noordwijk M et al (2011) Boundary work for sustainable development: natural resource management at the Consultative Group on International Agricultural Research (CGIAR). Proc Natl Acad Sci U S A. doi:10.1073/pnas.0900231108

Contreras-Hermosilla A, Fay C (2005) Strengthening forest management in Indonesia through land tenure reform: issues and framework for action. World Agroforestry Centre Southeast Asia, Bogor, Indonesia, Forest Trends

Corbera E (2012) Problematizing REDD+ as an experiment in payments for ecosystem services. Curr Op Sust. doi:10.1016/j.cosust.2012.09.010

Costanza R, Fisher B, Ali S (2007) Quality of life: an approach integrating opportunities, human needs, and subjective well-being. Ecol Econ 61:267-276

Culas R (2007) Deforestation and the environmental Kuznets curve: an institutional perspective. Ecol Econ $61: 429-437$

Danielsen F, Adrian T, Brofeldt S et al. (2013) Community monitoring for REDD+: international promises and field realities. Ecol Soc (in press)

Dermawan A, Petkova E, Sinaga A (2011) Preventing the risks of corruption in REDD+ in Indonesia: summary report. United Nations Office on Drugs and Crime, Jakarta, Center for International Forestry Research, Bogor

Dewi S, Ekadinata A, Galudra G, Agung P, Johana F (2011) LUWES: Land use planning for low emission development strategy. World Agroforestry Centre SEA Regional Office, Bogor

Dewi S, van Noordwijk M, Ekadinata A (2013) Protected areas in relation to landscape multifunctionality: squeezing out intermediate land use intensities in the tropics? Land Use Policy 30:38-56

Drew J, Drew M (2010) Establishing additionality: fraud vulnerabilities in the clean development mechanism. Account Res J 23(3):243-253

Edwards D, Koh L, Laurance W (2012) Indonesia's REDD+ pact: saving imperilled forests or business as usual? Biol Cons 151(1):41-44

Ekadinata A, van Noordwijk M, Dewi S et al. (2010) Reducing emissions from deforestation, inside and outside the 'forest'. ASB Brief 16. World Agroforestry Centre, Nairobi

Ekadinata A, Widayati A, Dewi S et al. (2011) Indonesia's land-use and land-cover changes and their trajectories 1990, 2000 and 2005. World Agroforestry Centre ICRAF, Bogor, Indonesia, p 6

Fitter R, Kaplinksy R (2001) Who gains from product rents as the coffee market becomes more differentiated? A value-chain analysis. IDS Bull 32:69-82

Galudra G, van Noordwijk M, Suyanto et al (2011) Hot spots of confusion: contested policies and competing carbon claims in the peatlands of Central Kalimantan (Indonesia). Int For Rev 13:431-441

Galudra G, Agung P, Noordwijk Mv et al. (2013) Migrants, land markets and carbon emissions: the drivers of land tenure change and the prospect of REDD+ in Jambi, Indonesia. Mit Adap Strat Glob Ch doi:10.1007/ s11027-013-9512-9

Gupta J (2012) Global forest and REDD+ governance: win-win or lose-lose? Curr Op Sust. doi:10.1016/ j.cosust.2012.09.014

Gupta A, Lövbrand E, Turnhout E et al (2012) In pursuit of carbon accountability: the politics of REDD+ measuring, reporting and verification system. Curr Op Sust. doi:10.1016/j.cosust.2012.10.004

Hoang M, Do T, Pham M et al (2012) Benefit distribution across scales to reduce emissions from deforestation and forest degradation (REDD+) in Vietnam. Land Use Policy. doi:10.1016/j.landusepol.2011.09.013

Hooijer A, Page S, Canadell JG, Silvius M, Kwadijk J, Wösten H, Jauhiainen J (2010) Current and future $\mathrm{CO}_{2}$ emissions from drained peatlands in Southeast Asia. Biogeosciences 7:1505-1514

Houghton R (2012) Carbon emissions and the drivers of deforestation and forest degradation in the tropics. Curr Op Sust. doi:10.1016/j.cosust.2012.06.006

IFCA (Indonesia Forest Carbon Alliance) (2007) REDDI: Reducing emissions from deforestation and forest degradation Indonesia. Jakarta. Ministry of Forestry 
Irawan S, Tacconi L, Ring I (2013) Stakeholders' incentives for land-use change and REDD+: the case of Indonesia. Ecol Econ 87:75-83

Kahneman D (2011) Thinking, fast and slow. Lane, London

Krott M, Bader A, Schusser C et al. (2013) Actor-centred power: the driving force in decentralised community based forest governance. For Pol Econ. http://www.sciencedirect.com/science/article/pii/ S1389934113000804

Larson A (2011) Forest tenure reform in the age of climate change: lessons for REDD+. Glob Environ Change 21(2):540-549. doi:10.1016/j.gloenvcha.2010.11.008

Lusiana B, van Noordwijk M, Cadisch G (2012) Land sparing or sharing? Exploring livestock fodder options in combination with land use zoning and consequences for livelihoods and net carbon stocks using the FALLOW model. Agric Ecosys Enviro 159:145-160

Lusiana B, van Noordwijk M, Johana F et al. (2013) Implication of uncertainty and scale in carbon emission estimates on locally appropriate designs to reduce emissions from deforestation and degradation (REDD+). Mit Adap Strat Glob Ch doi:10.1007/s11027-013-9501-z

Luttrell C, Resosudarmo I A P, Muharrom E et al. (2012) The political context of REDD+ in Indonesia: constituencies for change. Environ Sci Pol. http://www.sciencedirect.com/science/article/pii/ S1462901112001724

Lyster R (2011) REDD+, transparency, participation and resource rights: the role of law. Environ Sci Pol 14:118-126

Maslow A (1943) A theory of human motivation. Psych Rev 50:370-396

Melkas E (2002) Sovereignty and equity within the framework of the climate regime. Rev Eur Comm Intern Env Law 11:115-128

Mertz O, Muller D, Sikor T et al (2012) The forgotten D: challenges of addressing forest degradation in complex mosaic landscapes under REDD+. Danish J Geog. doi:10.1080/00167223.2012.709678

Meyfroidt P, Lambin E (2011) Global forest transition: prospects for an end to deforestation. Ann Rev Environ Res 36:343-371

Minang P, van Noordwijk M, Meyfroidt et al. (2010) Emissions Embodied in Trade (EET) and land use in tropical forest margins. ASB PolicyBrief 17. ASB Partnership for the Tropical Forest Margins, Nairobi

Minang P, van Noordwijk M (2012) Design challenges for achieving reduced emissions from deforestation and forest degradation through conservation: leveraging multiple paradigms at the tropical forest margins. Land Use Policy. doi:10.1016/j.landusepol.2012.04.025

Minang P, van Noordwijk M, Swallow B (2012) High-carbon-stock rural development pathways in Asia and Africa: How improved land management can contribute to economic development and climate change mitigation. In: Nair PKR, Garrity DP (eds) Agroforestry: the future of global landuse. Springer, The Netherlands, pp 127-143

Mulia R, Widayati A, Suyanto S et al. (2013) Low carbon emission development strategies for Jambi, Indonesia: simulation and trade-off analysis using the FALLOW model. Mit Adap Strat Glob Ch doi:10.1007/s11027-013-9485-8

Mulyani M, Jepson P (2013) REDD+ and forest governance in Indonesia: a multistakeholder study of perceived challenges and opportunities. J Env Dev. doi:10.1177/1070496513494203

Murdiyarso D, van Noordwijk M, Puntodewo A et al (2008) District scale prioritization for A/R CDM project activities in Indonesia in line with sustainable development objectives. Agric Ecosys Env 126:59-66

Murdiyarso D, Brockhaus M, Sunderlin W et al (2012) Some lessons learned from the first generation of REDD+activities. Curr Op Env Sus 4:678-685

Newell P, Pattberg P, Schroeder H (2012) Multiactor governance and the environment. Ann Rev Env Res 37:365-387

Olander L, Galik C, Kissinger G (2012) Operationalizing REDD+: scope of reduced emissions from deforestation and forest degradation. Curr Op Env Sus 4:661-669

Peters G, Marland G, Le Quéré C et al (2012) Rapid growth in CO2 emissions after the 2008-2009 global financial crisis. Nat Clim Ch 2:2-4

Phelps J, Friess D, Webb E (2012) Win-win REDD+ approaches belie carbon-biodiversity trade-offs. Biol Conserv 54:53-60

Pistorius T (2012) From RED to REDD+: the evolution of a forest-based mitigation approach for developing countries. Curr Op Sust. doi:10.1016/j.cosust.2012.07.002

Purnomo H, Arum G, Achdiawan R, Irawati R (2012) Rights and wellbeing: an analytical approach to global case comparison of community forestry. J Sus Dev 5(6):35-45

Purnomo H, Suyamto D, Irawati R (2013) Harnessing the climate commons: an agent-based modelling approach to making reducing emission from deforestation and degradation (REDD)+ work. Mit Adap Strat Glob Ch 18:471-489 
Resosudarmo I, Atmadja S, Ekaputri A et al. (2013) Does tenure security lead to REDD+ project effectiveness? Reflections from five emerging sites in Indonesia. World Dev. http://www.sciencedirect.com/ science/article/pii/S0305750X13000211

Romijn E, Ainembabazi J, Wijaya A et al (2013) Exploring different forest definitions and their impact on developing REDD+ reference emission levels: a case study for Indonesia. Environ Sci Policy 33:246-259

Santosa M, Khatarina J, Suwana A (2013) The progress on governing REDD+ in Indonesia. Int J Rural Law Policy. http://epress.lib.uts.edu.au/journals/index.php/ijrlp/article/view/3356

Streck C (2012) Financing REDD+: matching needs and ends. Curr Op Sust. doi:10.1016/j.cosust. 2012.10.001

Sunderlin W, Larson A, Duchelle A et al. (2013) How are REDD+ proponents addressing tenure problems? Evidence from Brazil, Cameroon, Tanzania, Indonesia, and Vietnam. World Dev. http:/www.sciencedirect.com/science/ article/pii/S0305750X13000193

Tadjbakhsh S, Chenoy A (2007) Human security: Concepts and implications. Routledge, London

Tata HL, van Noordwijk M, Ruysschaert D et al. (2013) Will reducing emissions from deforestation and degradation $(\mathrm{REDD}+)$ funding stop peat swamp conversion to oil palm in orangutan habitat in Tripa (Aceh, Sumatra, Indonesia)? Mitigation and Adaptation Strategies for Global Change (in press)

Thamrin S (2011) Indonesia's national mitigation actions: paving the way towards NAMAs. Presented at CCXG/Global Forum on Environment Seminar on MRV and Carbon Markets, 28-29 March 2011, Paris. http://www.oecd.org/dataoecd/52/45/48304156.pdf

Tomich TP, Chomitz K, Francisco H et al (2004) Asking the right questions: policy analysis and environmental problems at different scales. Agric Ecosys Env 104:5-18

Unger N (2012) Global climate forcing by criteria air pollutants. Ann Rev Env Res 37:1-24

Van Kooten G, Bogle T, de Vries FP (2012) Rent seeking and the smoke and mirrors game in the creation of forest sector carbon credits: an example from British Columbia. Resource Economics and Policy Analysis Research Group, Department of Economics, University of Victoria, Canada

Van Noordwijk M, Purnomo H, Peskett L et al. (2008a) Reducing emissions from deforestation and forest degradation (REDD) in Indonesia: options and challenges for fair and efficient payment distribution mechanisms. ICRAF Working Paper 81. World Agroforestry Centre, Bogor, Indonesia

Van Noordwijk M, Suyamto D, Lusiana B et al (2008b) Facilitating agroforestation of landscapes for sustainable benefits: tradeoffs between carbon stocks and local development benefits in Indonesia according to the FALLOW model. Agric Ecosys Env 126:98-112. doi:10.1016/j.agee.2008.01.016

Van Noordwijk M, Mulyoutami E, Sakuntaladewi N et al (2008c) Swiddens in transition: Shifted perceptions on shifting cultivators in Indonesia. World Agroforestry Centre Southeast Asia Regional Program, Bogor

Van Noordwijk M, Minang P, Dewi S, et al. (2009) Reducing Emissions from All Land Uses (REALU): the case for a whole landscape approach. ASB PolicyBrief 13. ASB Partnership for the Tropical Forest Margins, Nairobi. http://www.asb.cgiar.org/pdfwebdocs/ASBPB13.pdf

Van Noordwijk M, Hoang M, Neufeldt H et al (2011) How trees and people can co-adapt to climate change: Reducing vulnerability through multifunctional agroforestry landscapes. World Agroforestry Centre, Nairobi

Van Noordwijk M, Leimona B, Jindal R et al (2012) Payments for Environmental Services: evolution towards efficient and fair incentives for multifunctional landscapes. Ann Rev Environ Res 37:389-420

Venter O, Koh L (2012) Reducing emissions from deforestation and forest degradation (REDD+): game changer or just another quick fix? Anna New York Acad Sci 1249(1):137-150

Venter O, Possingham H, Hovani L et al. (2012) Using systematic conservation planning to minimize REDD+ conflict with agriculture and logging in the tropics. doi: 10.1111/j.1755-263X.2012.00287.x

Villamor GB, Desrianti F, Akiefnawati R et al. (2013) Gender influences decisions to change land use practices in the tropical forest margins of Jambi, Indonesia. Mitig Adapt Strateg Glob Change. doi: 10.1007/s11027-0139478-7

Wells P, Franklin N, Gunarso P et al. (2012) Indonesian constitutional court ruling number 45/PUU_-IX/2011 in relation to forest lands; implications for forests, development and REDD + . Daemeter consulting and Tropenbos International, Indonesia. http://www.daemeter.org/wp-content/files/Policy_Brief_ Constitutional_Court_Decision_No_45_PUUIX_2011.pdf

World Bank (2007) Sustaining economic growth, rural livelihoods, and environmental benefits: Strategic options for forest assistance in Indonesia. World Bank, Jakarta

Wösten JHM, Clymans E, Page SE, Rieley JO, Limin SH (2008) Peat-water interrelationships in a tropical peatland ecosystem in Southeast Asia. Catena 73:212-224 